\title{
SURVEY ON COMPETENCE AND ADMINISTRATION OF SUPERVISORY BOARD ACTIVITIES IN GERMAN STOCK-LISTED COMPANIES
}

\author{
Knut J. MICHELBERGER \\ University of Latvia, Latvia \\ Corresponding author e-mail: knut.michelberger@kmgib.com
}

\begin{abstract}
According to the agency theory (Jensen \& Meckling 1976), it is expected that there exists a positive relationship between corporate governance and company performance which is also generally assumed in recent research (Dignam \& Galanis 2016). This relationship is investigated in the study performed by the author of this paper. Two different approaches were chosen in parallel: (1) quantitative data analysis, based on financial figures and corporate governance variables, and (2) a survey of supervisory board members of listed German companies. This paper is about the results of structured interviews with 30 supervisory board members. The survey confirms that corporate governance regulations have an important influence on the administration of supervisory board activities and on board competence. Many supervisory board members stated that the German Corporate Governance Codex leads to extended meeting time to fulfil regulatory requirements, more data requirements to identify and estimate risk issues and to rising risk awareness. The interview results converge with the results from the multivariate analysis.
\end{abstract}

Keywords: Corporate governance, firm performance, board structure, board competence.

\section{INTRODUCTION}

The failure of several corporations (Enron, Tyco, Parmalat, Skandia, Lehman Brothers, etc.) in the last decade made it clear that firms should undergo further modifications in their corporate governance (CG) to increase transparency and to guarantee shareholders' reliance on directors' management. There seems to be a large consensus among both academics and professionals that new efforts are important to improve corporate governance practices to protect the shareholders' interests and to stabilize the basics of market economy due to the fact that many scholars, economic analysts and corporate practitioners have linked the severity and increasingly circular nature of financial and economic crises to failures of corporate governance (Sun, Stewart and Pollard, 2011; Gupta, Chandrasekhar and Tourani$\operatorname{Rad} 2013)$.

The term "corporate governance" summarizes efforts to optimize a company's management system and its monitoring and is based mainly on the agency theory and the problem of information asymmetries (Schillhofer, 2003). The essence of the agency theory is the separation of management and finance, or - in more standard terminology - the separation of management, ownership and control. 
This paper widens its scope by including soft factors. Apart from the formal structure of governance defined in the codices such as the German Corporate Governance Codex, another dimension of corporate governance has become of an increasing interest in the last years in the framework of the financial crisis. Some studies such as the most recent empirical research within this framework by Hau and Thum (2010) have examined the effect of distinct board competence in the framework of financial crises.

The overall objective of the author's research is to find out whether good corporate governance and board competence explain firm performance differences. Two different approaches are chosen in parallel: (1) quantitative data analysis, based on financial figures and corporate governance variables, and (2) an expert survey of supervisory board members out of this sample. The subject of this paper is related to the expert survey. The aim is to investigate the competence scope and administration of supervisory board activities.

\section{THEORIES AND CORE CONCEPTS OF CORPORATE GOVERNANCE ${ }^{1}$}

\subsection{The Development of New Institutional Economics as the Foundation of Corporate Governance Theory}

New institutional economics (NIE) is a theory of economics studying the effect of institutions on economic entities (Breuer, 2010; Hlaváček, J. and Hlaváček, M., 2013). Institutions - as defined in the new institutional economics - are formal and informal rules, including mechanisms for enforcing rules restricting the behaviour of individuals in transactions, therefore, leading to sub-efficient solutions (Richter, 2016). Williamson (1971) intensively discussed transaction costs and their impact on the efficiency of organizations (Frey, 2013). He treated organizational failures in the context of transaction costs. His main hypothesis was that markets and hierarchies represent the alternative forms of coordinating work for the organization and concluded that weaknesses of both forms of coordination must be compared in the decision-making process regarding make-or-buy decisions (Krzeminska, 2008). However, from the perspective of new institutional economics, the market is only one of several possible forms of coordination, such as hierarchy, firm, and network (Richter, 2016). New institutional economics, therefore, examines how these different forms of coordination emerge and what effects result from it. Special attention is given to reasons for suboptimal results of transactions, such as market efficiencies and the use of goods. New institutional economics asks not only for the institutional reasons for the particular design and efficiency of transactions but also

${ }^{1}$ See a more detailed review in: Michelberger, K. J. (2016). Corporate Governance Effects on Firm Performance: A Literature Review. Journal of Regional Formation and Development Studies, 20(3), 84-95. https://doi.org/10.15181/rfds.v20i3.1346 
asks normatively how institutions should be designed to operate efficiently (Richter, 2016).

\subsection{The "Theory" of Corporate Governance}

The corporate governance discourse has its origin in the so-called agency problem which arose in the academic debate of the 1930s, yielding the issue of disparity between the shareholders' interests (the principals) and management (agents) and the search for efficient management and control options. Jensen and Meckling (1976) are the co-founders of the principal-agent theory. Information asymmetry is a constituent characteristic of the principal-agent relationship, which can be used in different ways either in favour of or as a disadvantage to the principal (Dunn, 2013). The principal-agent theory offers a model to explain the actions of people and institutions in a hierarchy and the cost/benefit-effective design of contracts. Critique by Berle and Means (1932) forms the basis of the following discussions on the constitution of the corporation until today. The fundamental point of the critique by Berle and Means (1932) is what Mizruchi describes as "a usurpation $[\ldots]$ of power by the firm's managers. [...].

Peter Drucker claimed in 1951 that "a change in the legal construction of the rights of the investor should go hand in hand with the reorganization of the Board of Directors [...]. The Board should contain representatives of the investor, for after all he has a real interest in the conduct of business [...]. There should be [...] a number of full-time "management auditors" [...]. Such a Board would have the power to appoint the management or to remove it and have the final say on all major capital expenditures" (Drucker, 1951). In this respect, Drucker must be seen as the first researcher who pronounced the positive effects of management monitoring and stated that corporate governance needs professionalization. In this respect, Drucker provides a positive solution to the "bureaucratic crisis" identified by Schumpeter.

Friedman could be seen as the first person who argued that the management is not the "ruler" or the "administrator" of business but the executive agent of its owners, laying the foundation of the principal-agent theory. Consequently, according to Friedman (1970), the only responsibility of management is simply to increase profits on behalf of the principals. Therefore, any system of corporate governance must have as its basis recognition of that imperative corporate aim, which is profitability. In this respect, Friedman initiated (1970) the shareholder capitalism discussion, which finds its conceptual framework in Rappaport's (1981) concept of economic value for shareholders constituting the merger of the governance issue with the principal-agent theory. Rappaport (1981) defines: "A fundamental fiduciary responsibility of corporate managers and boards of directors is to create economic value for their shareholders."

Corporate governance defines the regulatory framework for the management and supervision of companies whereas the corporate governance framework is largely determined by legislators and owners (Spira, 2002). However, there is still no common understanding of a single definition of what good corporate governance exactly means (Stiglbauer, 2010; Berghe, 2012). Thus, good corporate governance is a very complex concept and includes compulsory and voluntary actions, regulations, and requirements such as adherence to laws and regulations 
(compliance), following accepted standards and recommendations as well as developing and following own corporate guidelines. Research in the field of corporate governance represents or frequently analyzes only some aspects of the corporate governance concept. In the following text, corporate governance is meant as it is defined in the Cadbury Commission Report. In the context of the theoretical discussion, corporate governance refers to the specific problems occurring from the separation between the company's direction and its ownership (Ampenberger et al., 2009). Therefore, the "original" meaning of the concept of corporate governance is: "Corporate Governance is, to a large extent, a set of mechanisms through which outside investors protect themselves against expropriation by insiders". (La Porta et al., 2000). "Good" corporate governance discourse aims at solving the principalagent problem by introducing a self-regulating system of contracts to avoid bureaucratic control and information asymmetries. The problem of managerial selfinterest is widely discussed in the framework of managerial (power) theory with the basic assumption that management compensation is often excessive, does not correlate to performance and increases the company's value and thus the owner's investment (Rappaport, 1981). The managerial (power) theory states that the agent (the executive) will serve his interests rather than those of the owners or shareholders (principals). Agency theorists do not explore the conduct, relationships, and attitudes that generate board effectiveness. Instead, they examine the effectiveness of various mechanisms designed to canalize the executive's selfinterest so that shareholder interests are served (Firth and Rui, 2012). Thus, the agency theory is highly influential in shaping the reform of corporate governance systems in terms of board-based mechanisms and external, market-based governance mechanisms (Solomon, 2007). Governance relies on its effectiveness of the transparency of financial information and the transparency of management decisions so that external "market" mechanisms can be effective through disciplinary effects on the company and thus on the executive performance (Berghe, 2012). In addition to these external market monitoring mechanisms, the agency theory discourse has shaped the internal boardroom reform. Maybe the most significant contributions in this context are in the form of the widespread adoption of performance-based executive compensation schemes (Bratton, 2012) which follows directly from the assumption that executive self-interest must be aligned with the shareholders' interests, for example, by value-based key performance indicator systems rewarding an increase of EVA (Zarbafi, 2011). Furthermore, the influence of agency theory can be seen in the promotion of corporate governance codices to strengthen the role of "control" of the supervisory board. In many countries, separation of the roles of chairman and chief executive as well as the "independence" of non-executive directors are set by law; the lead role of the nonexecutives on audit, remuneration, and nomination committees are increasingly strictly defined, which is all consistent with the agency theory assumption that shareholders' or owners' interests are potentially at risk in the absence of intensive independent non-executive monitoring. 


\subsection{The German Corporate Governance Code as a Good Corporate Governance System}

In the last 20 years, corporate governance codes were developed in many countries as recommendations for good corporate governance benchmarks not as legal requirements (Dine and Koutsias, 2013; Hopt, 2013). However, parts of these recommendations have a law-like character, because they are often used as a standard of good corporate governance for judging negligence of proper supervision and prudent management (Zhao, 2011). In every country, the basis of corporate governance is mainly the Company Law and the Stock Corporation Act. The main national difference is the separation of execution and supervision (Berghe, 2012). German law is one of the few examples that prescribes a two-tier system so that the executive board and supervisory board are separate bodies with different rights and duties. In Germany, the legal obligation of the supervisory board is to control and monitor the management (executive board) (Roth, 2013). Furthermore, the supervisory board depends on the consent with employee representatives, which have (provided the threshold of the number of employees is met) a third or half of the number of seats on the supervisory board, reflecting the consensus orientation of the German economic constitution. Additionally, the supervisory board has audit responsibilities, particularly concerning annual and financial statements as well as obligations to report to the shareholders' meeting (general meeting) (Talaulicar, 2012). The supervisory board dismisses and appoints executive directors (Tremml and Buecker, 2002).

In 1998, the German government passed the Law of Control and Transparency (KonTraG) which was the first actual corporate governance law in Germany (Lütz, 2009). The core of this law is the provision forcing companies to introduce and operate a company-wide early warning system and to publish statements about the company's risks and risk structure in a special report attached to the annual report. In 2000, the federal government set up a government commission on the modernization of company law due to the bankruptcy of one of Germany's largest construction companies. Among other things, the commission has recommended to develop the "Best Practice Code" for German companies. For this end, the "Government Commission on the German Corporate Governance Code" was formed as a self-regulation measure of the economy in 2001. The supervisory and executive boards of corporations are obliged annually to explain in the framework of the comply-or-explain policy. In 2010, further significant changes were adopted affecting the professionalizing of the supervisory board. In 2013, the Commission decided to structurally revise the Code and also deal with the issues of management board remuneration. The most important point is the recommendation to limit the board remuneration, including its variable parts (Janocha, 2014). A trend of a more or less full compliance with the code is observable in the last years, which some observers explain as a result of shareholder pressure. 


\section{PRIOR EMPIRICAL RESEARCH FINDINGS CONCERNING THE GERMAN GOVERNANCE SYSTEM AND FIRM PERFORMANCE. ${ }^{2}$}

Several studies until 1998 indicate that companies with good corporate governance have better long-term performance for shareholders or in terms of general business performance (e.g., Jensen, 1986; Hermalin \& Weisbach, 1991; Brickley et al., 1994; Shleifer \& Vishny, 1997). However, this observation period is just before the intensification of good corporate governance rules and laws marked by Sarbanes-Oxley Act (2002), the German Corporate Governance Code (2002), and several other initiatives, laws, codices in several other global leading economies. Shleifer and Vishny (1997) assert that "better-governed" firms have better operating performance because effective governance reduces control rights conferred by shareholders and creditors. Thus, Conheady et al. (2015) examine only Canadian-listed companies, Fuzi et al. (2016) focuses only on Malaysian-listed companies, Rose (2016) on Danish, and Akbar et al. (2016) on British-listed companies. However, further cross-country studies could not be identified in scientific journals for the last years. Concerning the German Corporate Governance Code and its effect on firm performance, only a few empirical studies were published in the last five years. Thus, for example, Stiglbauer (2010) has examined a set of 113 companies from the DAX30, TecDax, MDAX, and SDAX regarding firm-specific characteristics. Ebeling (2015) has examined the implementation degree of the corporate governance code and its effect on firm value among 54 companies of the German Real Estate Index (DIMAX). Mustaghni (2012) has examined the effect of good corporate governance on different performance indicators such as firm value (excess value (EV), actual value (AV), economic value added (EVA), and profitability (ROA and ROIC), including 85 German companies in the time period 2005-2008. He has found evidence of a slight effect of higher scoring for the supervisory board compensation policy on firm valuation (EV) for larger companies (Mustaghni, 2012). Other conclusions such as structure and quality of the supervisory board having a slightly positive effect on profitability are questionable. Furthermore, his study does not explain the rating agency scoring calculations, which may be the result of a lack of transparency on the side of the rating agency. Other studies, such as Roos (2005) and Scholz (2006), have investigated German companies for a period prior to 2005 or only with a limited focus such as in the study by Hau and Thum (2010) which investigated 29 banks and their board characteristics concerning their risk management in the financial crisis. Considering the discussed studies, it can be stated that the study of the author of this paper includes the largest sample (128 companies) with the longest observation period (5 years).

\footnotetext{
${ }^{2}$ See a more detailed review in: Michelberger, K. J. (2016). Corporate Governance Effects on Firm Performance: A Literature Review. Journal of Regional Formation and Development Studies, 20(3), 84-95. https://doi.org/10.15181/rfds.v20i3.1346
} 


\section{EXPERT SURVEY}

\subsection{Research Model}

Guided by prior research, a 13-factor research model of good corporate governance has been developed by the author of this paper (Michelberger, 2016). The research model as shown in Fig. 1 comprises the quantitative and qualitative parts of the study, while this paper focuses specifically on the qualitative part and board quality.

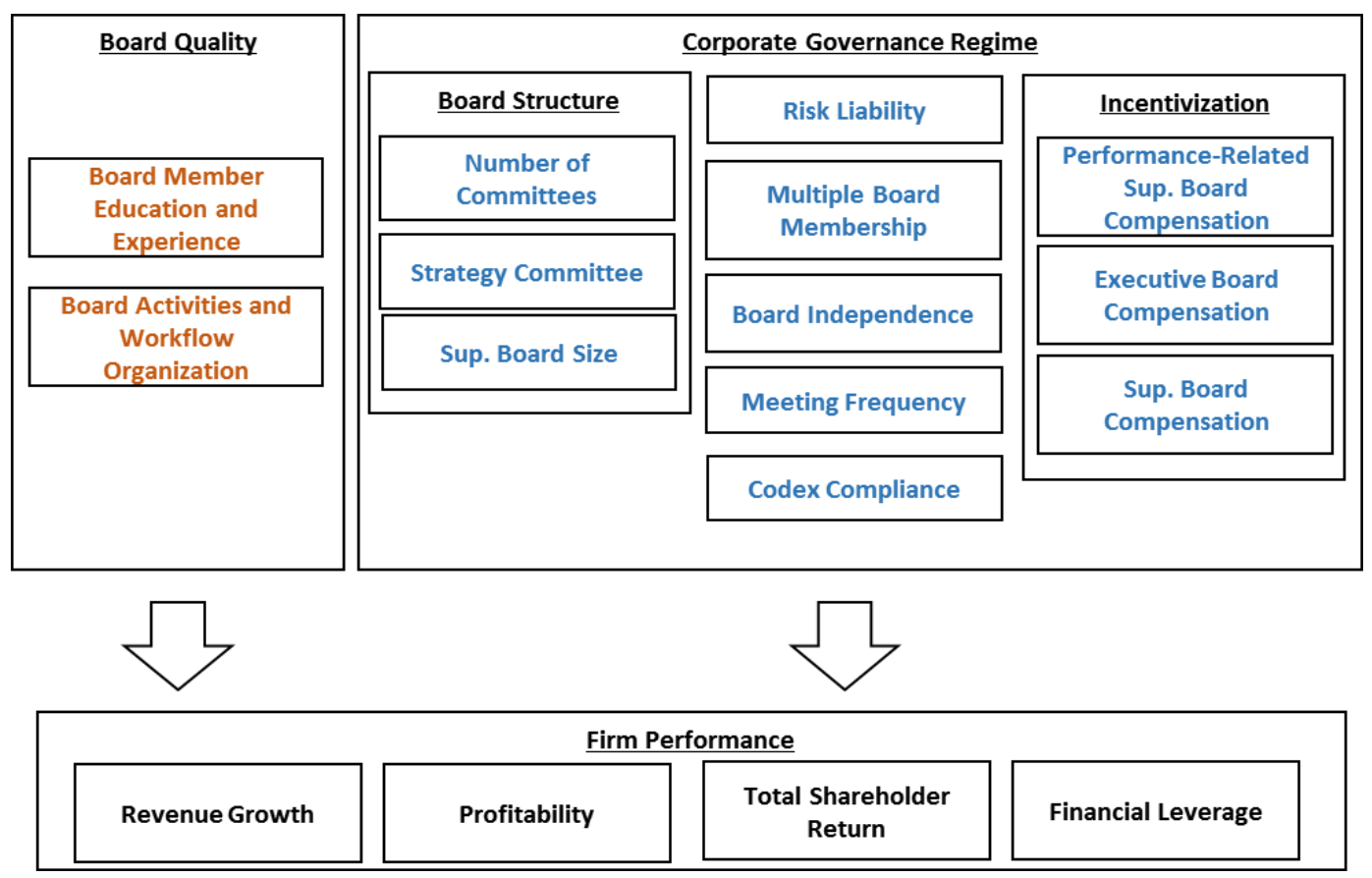

Fig. 1. 13-factors research model of good corporate governance.

Note. The factors in red are subject to the qualitative research, the factors in blue are subject to the quantitative research. Source: Author's presentation.

\subsection{Design of Survey}

The objective of the survey is to receive a deeper insight into the effects of the German Corporate Governance Code on board procedures and activities as well as on the required board competence.

Sample selection: The total group of companies is comprised of 128 German stock-listed companies and the number of all board members related to the group of companies selected is 1.786 . However, the total number of board members is comprised mostly of equal distribution of shareholders' and employees' representatives and 128 chairmen of the boards respectively. Originally, it was planned to conduct an extensive online survey with all addressable board members. However, this option had to be discarded due to the experience in the pre-test which showed that the interest in surveys was extremely limited among the target group and positive on-line responses were not received. Further data availability - 
particularly for smaller firms, where personal data for each supervisory board was not available, proved to be very limited. In the second approach, chairmen of the supervisory boards were approached by mail and telephone. 30 supervisory board members of the total investigated sample of 128 companies agreed on responding in expert interviews on behalf of their respective total boards, so that 30 complete boards of 128 boards were represented. The main characteristics of the final expert sample are:

- 5 respondents out of 30 serve as supervisory board chairmen;

- 5 respondents are female, 25 respondents are male;

- The average age is 61.6 years;

- The average period of service as supervisory board member accounts for 14.4 years;

- $97 \%$ of the respondents have served as CEO in the course of their professional life.

The questionnaire contains questions with set answers (multiple choice) and without set answers. The questions without set answers are summarized through sorting the answers by topics and the evaluation of statements respectively by interpretation or citation of statements.

The interviews were conducted mainly by phone; 6 interviews were conducted face-to-face.

\section{EXECUTION OF SURVEY AND RESPONSES TO QUESTIONS}

\subsection{The first question aims at the overall functioning and structure of board work.}

What is your definition of the quality of supervisory board work? Multiple answers were possible.

The answers were ranked and shown as percentage values. The results let assume, that the sample's supervisory board members see the quality of board work, firstly, in cooperation with the executive board, which is generally also the main task of the supervisory board by law and German Corporate Governance Code. Items concerning the internal organization of board work are valued as less important. The supervisory board member nomination process is of minor importance (see Fig. 2). 


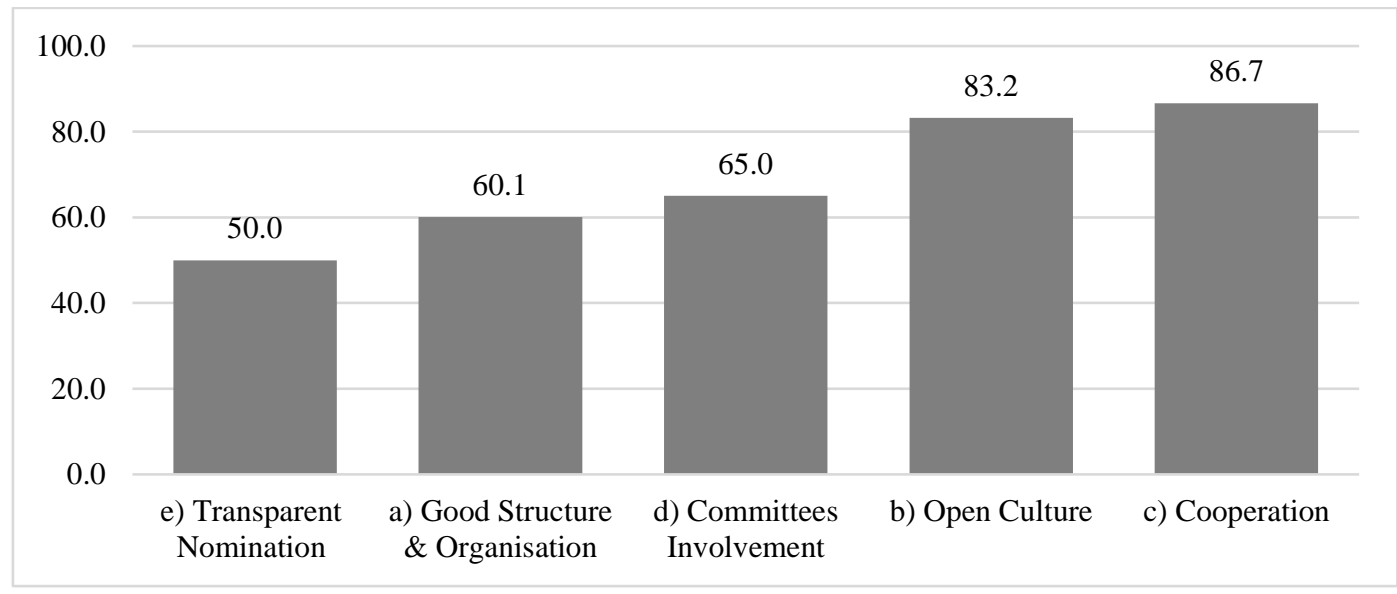

Fig. 2. Relevance of board items (\% of number of total respondents). Source: Author's calculations based on survey data.

The results might be interpreted as that the respondents value the informal and direct cooperation between governance institutions higher.

4.2. The second question relates to personality traits of supervisory board members.

Which three personality traits should a supervisory board member have to enhance the quality of work of the supervisory board?

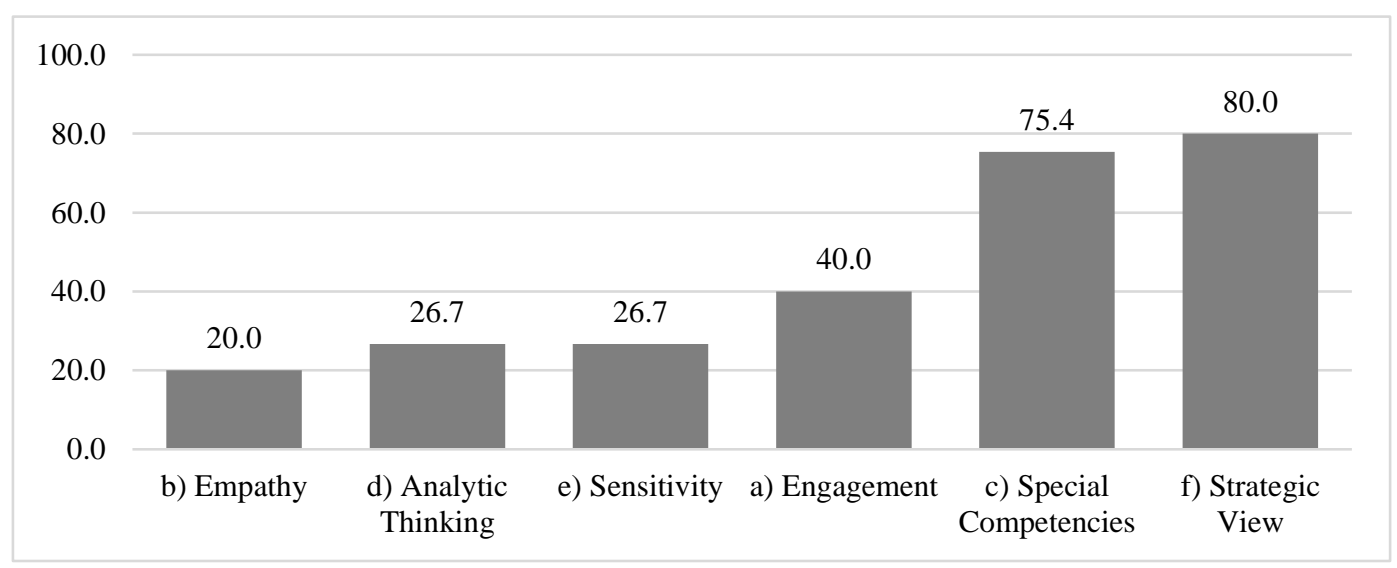

Fig. 3. Relevance of supervisory board member personal traits (\% of number of total respondents). Source: Author's calculations based on survey data.

It is noted that the results of Question 1 cannot be supported in regard to personal traits (see Fig. 3). Instead, the results show that formal competencies are preferred over informal abilities such as a strategic view (see Fig. 4). Accordingly, in the context of Question 1, it is stated, that the majority of the respondents tend to prefer the mix of formal and informal characteristics regarding individual qualification, while in the context of "daily operations" of the supervisory board informal values are preferred. This formal-informal mix is even more pronounced 
with the question regarding the competence areas of members and the board as an institution.

4.3. The third question relates to personal as well as to institutional competence.

This Question is divided into two sub-questions:

Which are the essential areas of competence that a supervisory board should have?

The item "cross-functional experience" refers to experience in different corporate areas such as marketing, $\mathrm{R} \& \mathrm{D}$, finance, etc.

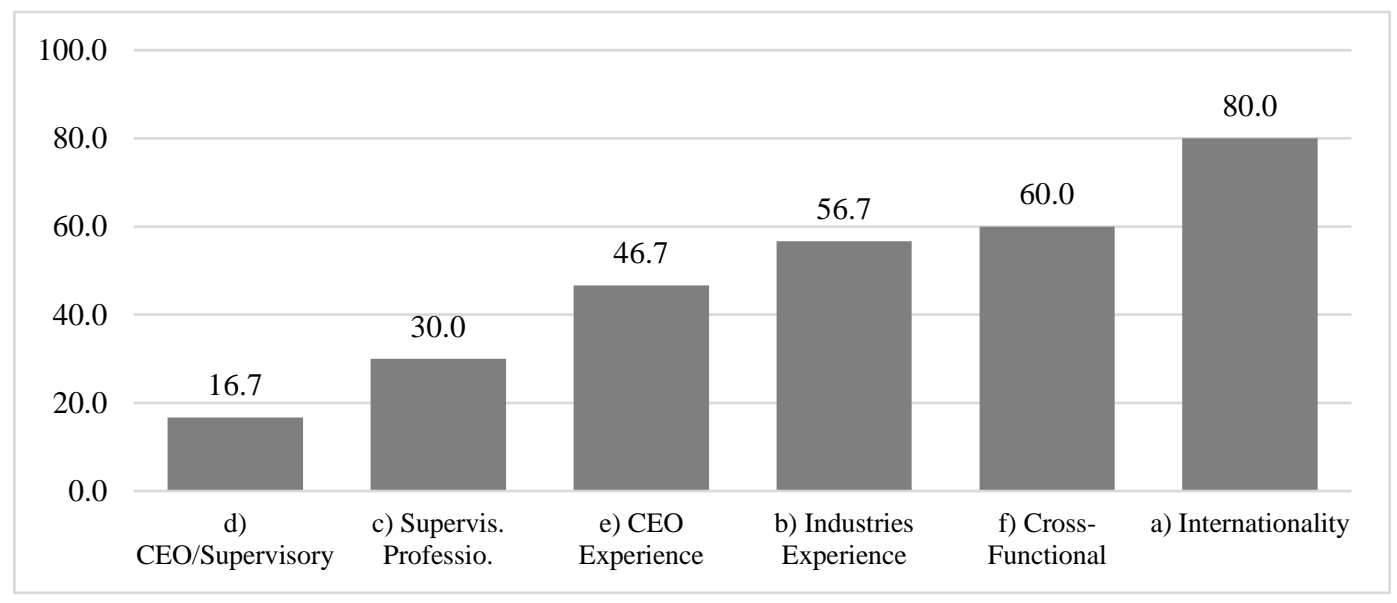

Fig. 4. Competence requirements for board members (\% of number of total respondents). Source: Author's calculations based on survey data.

Interdisciplinary experience with an international background is the requirement with the highest response frequency (see Fig. 4). Instead, formal experience as a supervisory board member (item (c) and (d)) are not often required. Thus, the requirement ranking looks more than a strategist profile. Furthermore, once again, the respondents refer stronger to soft skills and informal abilities than formal experience with supervisory board formalities such as supervisory board experience.

Which essential areas of competence shall the supervisory board have as governing body?

The item "Diversity" refers not only to gender diversity. However, the experience with the questionnaire in the survey leads to the assumption that mostly gender diversity is associated with this term. Therefore, the interpretation of this value refers to gender diversity. 


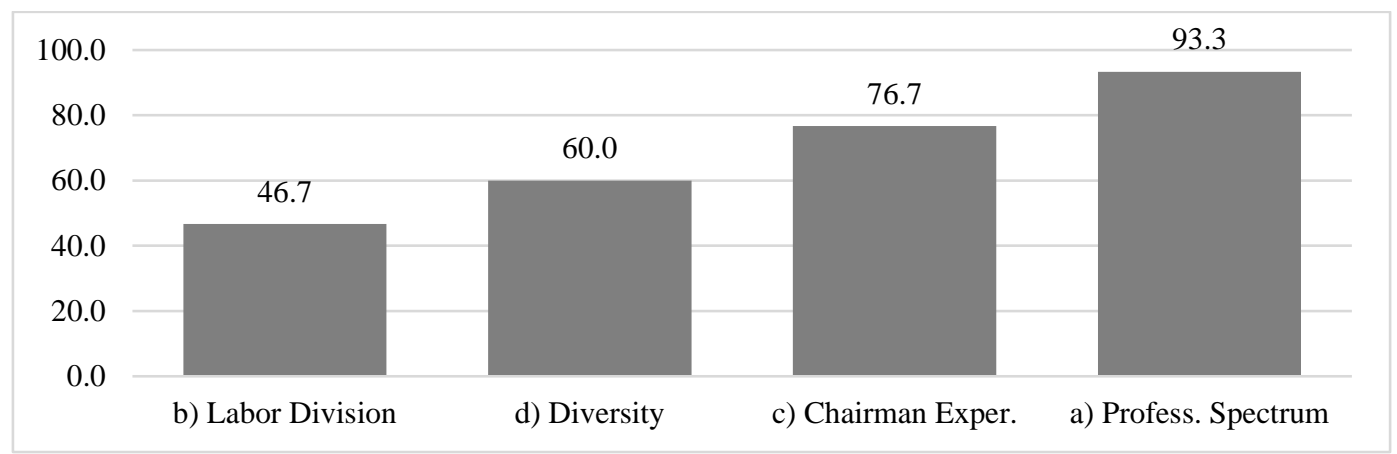

Fig. 5. Supervisory board competence characteristics (\% of number of total respondents). Source: Author's calculations based on survey data.

The respondents weighed the professional spectrum embodied in the supervisory board as extremely important with $93 \%$ (see Fig. 5), which is the second highest approval rate measured in all questions. Furthermore, the chairman is seen as the central element in the supervisory board activities. Instead, even diversity is surprisingly valued higher than the division of labour through committee formation.

4.4. Question 4 refers to the activity priorities of the supervisory board and provides an idea of the supervisory board members' understanding of their own role.

Which activities do you consider as the most important task of the supervisory board?

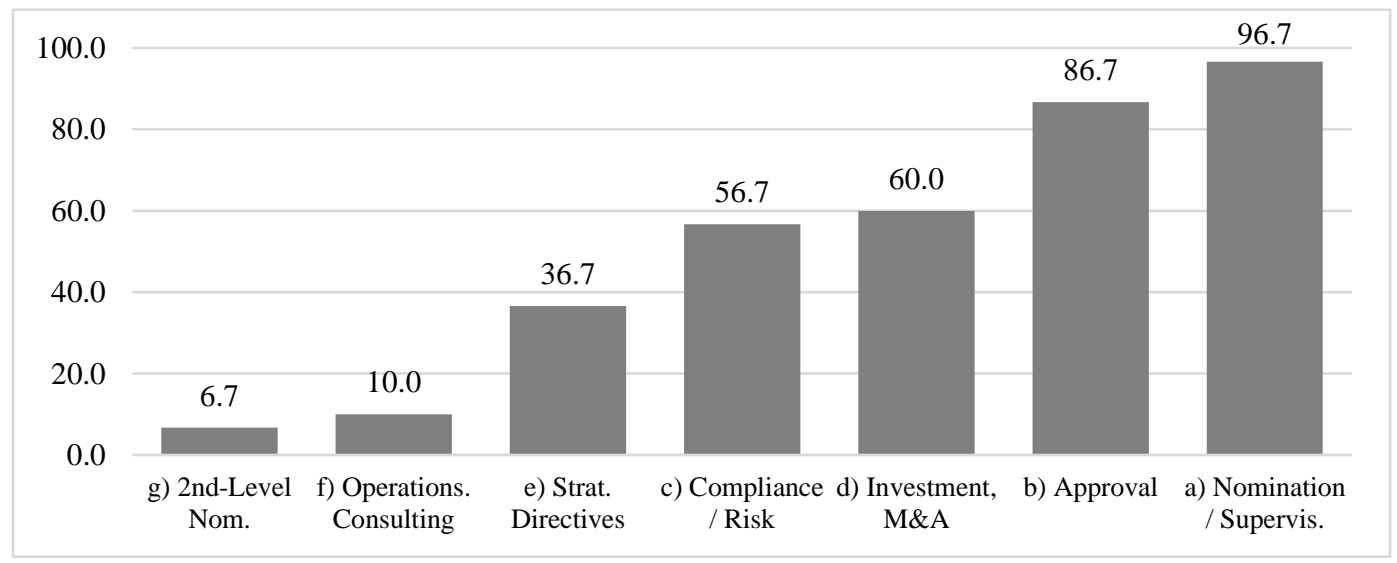

Fig. 6. Activity priorities of the supervisory board (\% of number of total respondents). Source: Author's calculations based on survey data.

Contrary to the previous assumptions, the supervisory board members' understanding of their role shows high formalism. While all other questions indicate preference for informal items, the supervisory board members see their role as strictly formal with $96 \%$ approval rate concerning formal activities for nomination and supervision of the executive board (see Fig. 6). Instead, strategic and 
operational issues were not seen as priority activities. Thus, it can be concluded, that the tendency to informal abilities and procedures does not mean that the interviewed supervisory board members reject formalism. Rather, they distinguish clearly between necessary formalization and the regulatory framework requirements. This becomes even clearer in the answers to Question 6.

4.5. Question 5 is a question without set answers, referring to the changes of the supervisory board practices in the last decade.

From your experience as a supervisory board member, how have supervisory board practices changed in the last 10 years? Please name positive and negative changes!

The answers regarding positive changes astonishingly often refer to the rising degree of formalization. Thus, one board member explains, that the supervisory board practice is more and more determined by standardized workflows, in particular, concerning risk and compliance issues. Here, the regulatory necessities lead to, on the one hand, more periodical reports and thus to a higher density of company data and information. On the other hand, the increasing corporate governance requirements lead to the information and formalization overload. One interviewee notes that the number of resolutions has increased due to regulatory requirements, because the increasing liability risks lead to elevation of "approval barriers" concerning executive board decisions. Another respondent mentions that the rising number of committees and the rising intensity of committee work leads to a "two-classes society" in the board room: While the members who are active in committees are increasingly better informed, board members without membership in committees receive less information. The major parts of the statements to Question 5 refer to information, communication, regulation, reporting, formalization, and the division of labour. On the one hand, the majority of positive statements refer to the positive effects of board workflow structuring and the continued information flow due to regulations, while, on the other hand, the same interviewees mention the problem of work intensification, increasing coordination efforts and excessive formalization. Furthermore, one member states, that the board Independency rules have led to the selection of new members based on their expertise not on their membership in a social network. One responded observes in several supervisory boards, in which he is a member, a trend towards "complementary diversity". Members are nominated more and more due to their complementary experience and knowledge. Furthermore, 7 interviewees remarked explicitly, that the board work is strongly influenced by liability risks, in particular, concerning the direction of discussions, where the discussions on liability risks are more and more resulting in a slow decision-making, lengthy discussions and the need for additional data. One respondent even observes that more and more supervisory board member candidates reject the nomination due to liability risks. 
4.6. Question 6 relates to the quality of supervisory work.

If you are in the German Corporate Governance Code Committee: Which essential change would you propose in order to increase the quality of supervisory board activities?

With the exception of one respondent, all other interviewees provided statements criticizing the high density of the German Corporate Governance Code regulations. Only one supervisory board member proposes a supplement to the existing rules. She proposes, that the supervisory board should have an own budget to buy in external expertise in the form of special reports and ratings concerning different aspects such as, for example, compliance auditing and risk management. All other respondents note that the existing regulatory framework is partially excessive and leads to bigger efforts without higher efficiency regarding the monitoring tasks or regarding the main task which is serving the shareholders' interests. However, one respondent explains explicitly that the German Corporate Governance Code has made an important contribution to avoiding principal-agent issues.

\subsection{Summary of Survey}

The survey's major findings are the following:

1. Most of the regulations, particularly in the form of the German Corporate Governance Code, have had an important influence on the quality of supervisory board activities and board procedures. This applies in particular regarding the information provision, board independence, board diversity in various dimensions and other requirements.

2. The refining of the code concerning the management's reporting duties has led to information exchange between the management board and supervisory board so that more information is available particularly through periodical reports. However, the information is not equally distributed. It seems as if the constant stream of information exists mainly between the committees and the management whereas supervisory board members who are not committee members do not dispose on additional information.

3. The increasing codification concerning committee issues has led to an increasing number of committees which leads, on the one hand, to a higher information density in the context of decisions-making, but has intensified the work load in the committees so that more supervisory board members who are also committee members have to invest more time in committee work.

4. The interviewed supervisory board members understand their role as strictly separated from the management decision making. Strategic and operational decision-making remains in the realm of the executive board, whereas the supervisory board remains a monitoring entity in the corporate governance structure, but the nomination and the selection of new members is more rational and not dominated by social networks.

5. Informal and specific competence is more required than business skills such as industry experience, CEO experience or supervisory experience. On the 
contrary, the ability to cooperate, internationality, strategic view or specific skills such as financial skills or legal abilities seem to be more required.

\section{CONCLUSION}

From the results of the survey, the author draws the following conclusions:

1. Highest possible compliance with good corporate governance procedures defined by the German Corporate Governance Code leads to risk aversion and administrative overload so that entrepreneurial thinking is replaced by formalism and does not provide benefit for principals. Especially, high ownrisk deductibles in D\&O policies lead to risk-averse supervisory board behaviour and thus to lower total shareholder return growth.

2. Further formalization of corporate governance by the regulator is correlated with the decrease of marginal utility. Future issues of governance regulation lies not in the problem of under-regulation but more in the field of over-regulation, which results in inefficiencies concerning the protection of shareholder interests or public interest, but much more in limitations regarding business activities. If risk-taking is more and more avoided due to regulatory activities, then the main driver of firm performance, which is entrepreneurship, will be lost.

Based on the conducted research, the author has the following recommendations:

1) The Commission of the German Governance Code more intensively deal with subjects related to the supervisory board and company cultures. The challenge here is the consensus-oriented culture within German corporations. The increasing adaption of voluntary code recommendations into the legal body and the requirement for explanation (comply or explain) are to be questioned. It needs to be clarified and clearly labelled which of the codex regulations are voluntary or already legal bodies. Also the reporting instruments of the governance reporting as to compliance declaration, management report, corporate governance report, annual report and efficiency review of the supervisory board are to be harmonized. Also, governance measures as a result of non-compliance with codex recommendations are to be clarified. Further, the risk liability of supervisory board members should be reduced to avoid risk aversion.

2) Chairmen of supervisory boards do not follow the German Corporate Governance Code in every single paragraph. Instead, it is to be critically addressed if the degree of compliance is dysfunctional concerning firm growth, profitability and shareholder return causing only administrative costs to fulfil the compliance requirements. In any case, the level of compliance is to be accommodated with the lifecycle stage and the corporate strategic preferences of the company. As to board activities and workflow it is recommended to professionalize working procedures of the board so that board members can extent their full attention to the development of firm performance instead of formal and administrative requirements imposed by the regulations. Therefore, 
the supervisory board would need independently be able to dispose of an own budget to buy-in the necessary competence for a limited period of time.

3) Scientists do extend the study in size by including stock listed companies of other countries with equivalent corporate governance regulations and to look into the supervisory board black-box researching the interactions with view to their impact on firm performance.

\section{REFERENCES}

Ampenberger, M., \& Schmid, T., Kaserer, C., \& Achleitner, A. (2009). Family preferences and payout policy decisions: Are there differences between family ownership and management? Munich: TU Munich.

Akbar, S., Poletti-Hughes, J., El-Faitouri, R., \& Shah, S. Z. A. (2016). More on the relationship between corporate governance and firm performance in the UK: Evidence from the application of generalized method of moments estimation. Research in International Business and Finance, 38, 417-429. https://doi.org/10.1016/j.ribaf.2016.03.009

Berle, A. \& Means, G. C. (1932). The Modern Corporation and Private Property. New York: Macmillan.

Berghe, A. (2012). International Standardisation of Good Corporate Governance: Best Practices for the Board of Directors (2nd ed.). Dordrecht, Springer Science.

Bratton, W. (2012). Agency theory and incentive compensation. In Research handbook on executive pay. Cheltenham [u.a.] : Edward Elgar, ISBN 978-1-84980-396-0. pp. 101-119.

Breuer, M. S. D. (2010). Socio-Cognitive Dynamics in Strategic Processes. Köln: EUL.

Brickley, J. A., \& James, C. M. (1987). The Takeover Market, Corporate Board Composition and Ownership Structure: The Case of Banking. Journal of Law and Economics, 30, 161-180. https://doi.org/10.1086/467134

Conheady, B., McIlkenny, P., Opong, K. K., \& Pignatel, I. (2015). Board effectiveness and firm performance of Canadian listed firms. The British Accounting Review, 47(3), 290-303. https://doi.org/10.1016/j.bar.2014.02.002

Dunn, M. (2013). Inside the Capitalist Firm: An Evolutionary Theory of the Principal-AgentRelation. Potsdam: Potsdam University Press.

Dignam, A. \& Galanis, M. (2016). The Globalization of Corporate Governance (2nd ed.). Milton Park: Routledge, p. 154.

Dine, J. \& Koutsias, M. (2013). The Nature of Corporate Governance. Cheltenham: Edward Elgar, p. 63.

Drucker, P. (1951). The New Society. The Anatomy of the Industrial Order. London: William Heinemann.

Drucker, P. (1993) Management: Tasks, Responsibilities, Practices. New York: Harper \& Row.

Ebeling, P.-C. (2015). Corporate Governance kapitalmarktorientierter Immobiliengesellschaften (Schriften zu Immobilienökonomie und Immobilienrecht. Regensburg: International Real Estate Business School.

Firth, M. A., \& Rui, O. M. (2012). Does One Size Fit All? A Study of the Simultaneous Relations Among Ownership, Corporate Governance Mechanisms, and the Financial Performance of Firms in China. In S. Boubaker, B. D. Nguyen, \& D. K. Nguyen, (eds), Corporate Governance: Recent Developments and New Trends (pp. 29-58). Heidelberg: Springer.

Frey, C. B. (2013). Intellectual Property Rights and the Financing of Technological Innovation: Public Policy and the Efficiency of Capital Markets. Cheltenham: Edward Elgar, p. 105.

Friedman, M. (1970). The Social Responsibility of Business is to Increase its Profits, The New York Times Magazine (23 September 1970), 32-33.

Fuzi, S. F. S., Halim, S. A. A., \& Julizaerma, M. K. (2016). Board Independence and Firm Performance. Procedia Economics and Finance, 37, 460-465. https://doi.org/10.1016/S2212$\underline{5671(16) 30152-6}$ 
Gupta, K., Chandrasekhar, K., \& Tourani-Rad, A. (2013). Is corporate governance relevant during the financial crisis? Journal of International Financial Markets, Institutions and Money, 23, 85110. https://doi.org/10.2469/dig.v43.n3.8

Hau, H., \& Thum, M. (2010). Subprime Crisis and Board (In-)Competence: Private vs. Public Banks in Germany. Fontainebleau: INSEAD.

Hermalin, B., \& Weisbach, M. S. (1991). The effects of board composition \& direct incentives on firm performance. Financial Management, 20(4), 101-112. http://www.jstor.org/stable/3665716

Hlaváček, J., \& Hlaváček, M. (2013). Generalized Microeconomics. Prague: University of Prague.

Hopt, K. J. (2013). Some Corporate Governance Thoughts from Europe. In P. Davies, P. L. Davies, K. J. Hopt, R. Nowak \& G. Solinge (eds.), Corporate Boards in European Law: A Comparative Analysis (pp. 531-562). Oxford: Oxford University Press.

Janocha, M. (2014). Vergütung mittels Bonusbanken: Eine agency-theoretische Perspektive.Wiesbaden: Gabler.

Jensen, M. (1986). The Agency Costs of Free Cash Flow. American Economic Review, 76, 326329.

Jensen, M. C. \& Meckling, W. H. (1976). Theory of the firm: managerial behavior, agency costs \& ownership structure. Journal of Financial Economics, 3(4), 305-360.

Krzeminska, A. (2008). Determinants and Management of Make-and-Buy: An Extension to Transaction Cost Economics. Wiesbaden: Gabler.

La Porta, R., Lopez-de-Silanes, F., Shleifer, A., \& Vishny, R. (2000). Investor protection and corporate governance. Journal of Financial Economics, 58, 3-27. https://doi.org/10.1016/S0304-405X(00)00065-9

Lütz, S. (2009). The Finance Sector in Transition: A Motor for Economic Reform?.In K. Dyson \& S. Padgett (eds.), The Politics of Economic Reform in Germany: Global, Rhineland Or Hybrid Capitalism (pp. 26-42). London: Routledge.

Michelberger, K. J. (2016). Impact of Corporate Governance on Firm Performance and Total Shareholder Return of German Listed Companies, Doctoral Thesis Submitted at the University of Latvia.

Michelberger, K. J. (2016). Corporate Governance Effects on Firm Performance: A Literature Review. Journal of Regional Formation and Development Studies, 3(20), 84-95. https://doi.org/10.15181/rfds.v20i3.1346

Mustaghni, B. (2012). Einfluss von Corporate Governance auf den Erfolg von Unternehmen: eine Untersuchung börsennotierter Unternehmen in Deutschland (Europäische Hochschulschriften). Bern: Lang.

Rappaport, A. (1981). Selecting Strategies that Create Share. Harvard Business Review, 59, 139149.

Richter, R. (2016). Essays on New Institutional Economics. Heidelberg: Springer, p. 66.

Rose, C. (2016). Firm performance and comply or explain disclosure in corporate governance. European Management Journal, 34(3), 202-222. https://doi.org/10.1016/j.emj.2016.03.003

Roth, M. (2013). Corporate Boards in Germany. In P. Davies, P. L. Davies, K. J. Hopt, R. Nowak \& G. Solinge (eds.), Corporate Boards in European Law: A Comparative Analysis (pp. 253366). Oxford: Oxford University Press.

Roos, S. (2005). Unternehmensperformance nach Vorstandswechsel: Eine empirische Analyse zur Effizienz deutscher Aufsichtsräte. Würzburg: Universität Würzburg.

Schillhofer, A. (2003). Corporate Governance and Expected Stock Returns: Empirical Evidence from Germany. Wiesbaden: DUV.

Scholz, F. (2006). Determinanten von Aufsichtsratsarbeit und ihre Entwicklung. Eine explorative Studie mit Insidern über Aufsichtsräte börsennotierter deutscher Aktiengesellschaften. Bielefeld: Universität Bielefeld.

Shleifer, A., \& Vishny, R. W. (1997). A survey of corporate governance. Journal of Finance, 52(2), 737-783. http://doi.org/10.1111/j.1540-6261.1997.tb04820.x

Solomon, J. (2007). Corporate Governance and Accountability. Chichester: Wiley.

Spira, L. (2002). The Audit Committee: Performing Corporate Governance. New York: Kluwer.

Stiglbauer, M. (2010): Corporate Governance Berichterstattung und Unternehmenserfolg: Eine empirische Untersuchung für den deutschen Aktienmarkt. Wiesbaden: Springer Gabler. 
Sun, W., Stewart, J., \& Pollard, D. (Eds.). (2011). Corporate Governance and the Global Financial Crisis. Cambridge University Press, Cambridge.

Talaulicar, T. (2012). Corporate Governance and Initial Public Offerings in Germany. In A. Zattoni \& W. Judge (eds.), Corporate Governance and Initial Public Offerings: An International Perspective (pp. 141-166). Cambridge: Cambridge University Press.

Tremml, B., \& Buecker, B. (2002). Recognized Forms of Business Organization.In M. Wendler, B. Tremml \& B. J. Buecker (eds), Key Aspects of German Business Law: A Practical Manual (2 ${ }^{\text {nd }}$ ed.) (pp. 7-30). Berlin: Springer.

Zarbafi, E. M. (2011). Responsible Investment and the Claim of Corporate Change: A Sensemaking Perspective. Wiesbaden: Springer.

Zhao, Y. (2011). Corporate Governance and Directors' Independence. Alphen: Kluwer Law.

\section{AUTHOR'S SHORT BIOGRAPHY}

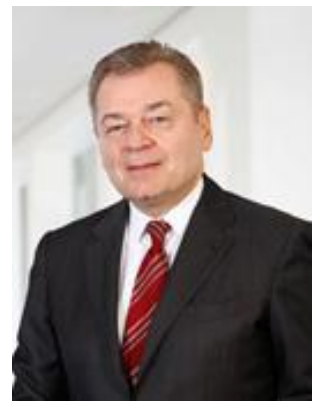

Knut J. Michelberger studied Mechanical Engineering and Business Administration and obtained Dipl. Ing. and Dipl. Ök. from Bergische Universität Wuppertal and Ruhr Universität Bochum in 1969 and 1976, respectively. From 2013 to 2016 he has been a doctoral student with the Department of International Economics and Business, Faculty of Economics and Management, the University of Latvia, and will defended the Thesis in 2017. He is a self-employed CONSULTANT and serves as a member of several supervisory boards in Germany and in the Netherlands. His research interest is Corporate Governance. 